\title{
Práctica artística como reivindicación social en la infancia y la tercera edad: comportamiento y reflexión ante la creación de prácticas artísticas colectivas/comunitarias.
}

Art practice as a social demand in childhood and the elderly: behavior and reflexion on the creation of collective / community artistic practices

\section{Deborah Sanabrias Moreno}

AASA (Acción Social por el Arte) Jaén, España..

deborah_sanabrias@hotmail.com

Recibido 06/03/2018

Aceptado 14/06/2018
Revisado 10/06/2018

Publicado 01/07/2018

\section{Resumen}

Este artículo recoge la experiencia de una investigación educativa basada en las artes, donde se ha acercado el ámbito artístico al alumnado de educación infantil y a personas de la tercera edad, con el fin de conocer las preocupaciones sociales existentes en la población de estas edades y usar el arte como medio de expresión y comunicación colectiva. De igual modo, se ha pretendido analizar cuáles son las posibles diferencias existentes en el comportamiento mostrado ante la creación de una práctica artística en ambos grupos de sujetos investigados.
Abstract

This article brings together the experience of educational research based on the arts, where has approached the art world of early chilhood education and people of the third age, in order to meet social concerns existing in the population of this age and use art as a means of expression and collective communication.

Similarly, we have tried to analyse what are the possible differences in the shown behavior the creation of a practice in both groups of subjects investigated.

Para citar este artículo

Sanabrias Moreno, Deborah (2018). Práctica artística como reivindicación social en la infancia y la tercera edad: comportamiento y reflexión ante la creación de prácticas artísticas colectivas/comunitarias. Tercio Creciente, 14, págs. 109-130. https://dx.doi.org/10.17561/rtc.n14.9org/10.17561/rtc.n14.9 
Revista de Estudios en Sociedad,

Artes y Gestión Cultural

Número 14

Julio 2018

www.terciocreciente.com

Investigación
ISSN: 2340-9096

DOI: https://dx.doi.org/10.17561/rtc.n14.9
http://revistaselectronicas.ujaen.es/index.php/RTC

Palabras clave / Keywords

Artivismo, arte, infancia, tercera edad, reivindicación social

Artivism, art, childhood, old age, vindication

Para citar este artículo

Sanabrias Moreno, Deborah (2018). Práctica artística como reivindicación social en la infancia y la tercera edad: comportamiento y reflexión ante la creación de prácticas artísticas colectivas/comunitarias. Tercio Creciente, 14, págs. 109-130. https://dx.doi.org/10.17561/rtc.n14.9 


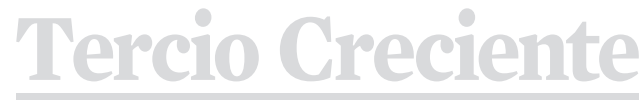

ISSN: 2340-9096

DOI: https://dx.doi.org/10.17561/rtc.n14.9

Investigación

\section{Introducción}

Este artículo constituye la culminación de una investigación artística basada en las artes, en la que se ha pretendido acercar la práctica artística al alumnado de educación infantil y a personas de la tercera edad. Estos dos grupos han sido elegidos concienzudamente debido a que representan por un lado, a la población más joven y más susceptible ante cualquier práctica artística como vía de desarrollo personal y social, pues encarnan el futuro en todos sus posibles ámbitos.

Y por otro lado, a la tercera edad, como visión de aquellas personas que quizás no conocen o no han vivenciado desde su propia experiencia una práctica artística de carácter contemporáneo y que a su vez, están sufriendo de manera muy directa todos los cambios sociales que estamos soportando en estos tiempos actuales y que sin lugar a dudas, se distancian mucho de lo vivido por ellos tiempo atrás.

Por todo ello, se ha considerado que el hecho de escuchar y plasmar de forma artística las preocupaciones o miedos que presentan ambos sectores podría ser una gran ayuda para intentar caminar hacia una sociedad más humana y libre, procurando concienciar a la sociedad en su conjunto, de la pronta necesidad de cambio ante algunas temáticas sociales. Así como, sensibilizar a la humanidad sobre los beneficios de usar el arte para conseguir dicho propósito y como beneficio personal para sus participantes.

La investigación fue por tanto realizada no solo con la intención de acercar el arte a dichos grupos sociales, sino con la necesidad de comprobar cuáles son las posibles diferencias mostradas en el comportamiento de ambos grupos de estudio ante la creación y vivencia de una práctica artística de carácter reivindicativo. Además de comprobar y detectar qué importancia le da al arte cada grupo social y cuáles son los beneficios que la práctica artística colectiva aporta a niños y ancianos.

En resumen, podríamos considerar la hipótesis de esta investigación, la siguiente:

¿Es válido el medio artístico como vía de conocimiento y reivindicación social en la infancia y la tercera edad? Y ¿cuál es la respuesta de estos grupos ante la realización de ciertas prácticas artísticas?

\section{Fundamento teórico}

La aparición de numerosas problemáticas sociales que inquietan a la sociedad del siglo XXI, ha dado lugar a cuantiosas protestas y reivindicaciones sociales, llevando a los ciudadanos a ocupar el espacio público para reivindicar por sus derechos de forma colectiva y colaborativa, tales protestas han tenido en muchas ocasiones cierto sentido artístico por lo que se ha dado lugar a un nuevo término denominado "artivismo". Término formado por las palabras arte y activismo, que engloba todas las manifestaciones artísticas que tienen relación con dichos palabras.

\subsection{Relación entre artivismo y arte comunitario}

El arte público existe y es posible gracias a la unión de grupos de personas que abogan por la defensa de un bien común y ello implica, 
haberse puesto de acuerdo y organizado acerca de cómo quieren transmitir de forma conjunta a la sociedad ese mensaje, es por tanto además, un arte colaborativo.

En la presente investigación cobra especial valor el hecho de realizar una práctica artística de modo conjunto, donde no solo pensemos de modo individual sobre qué consideramos que podría mejorarse o cambiarse, sino que conversemos con el resto y sea el resultado de esa reflexión o negociación conjunta, lo que origine la creación artística posterior.

La mayor parte de las prácticas artísticas que poseen un vínculo con el arte público, se inscriben también en el término denominado "arte comunitario o arte de la comunidad". La definición del arte comunitario ha tomado diferentes matices a lo largo de su evolución pero si nos centramos en los años setenta en lo referente a Gran Bretaña y Estados Unidos, este arte nace con el sentido de originar prácticas artísticas que requieran la colaboración y participación del público y que a su vez tienden a intentar mejorar el estado de la sociedad.

En estos términos cabe mencionar a Sally Morgan pionera de este tipo de arte en Gran Bretaña, quien en 1995 indicaba: "que si el arte comunitario es algo, es la manifestación de una ideología". Una ideología que abogaba por acercar la cultura a la sociedad, por crear una cultura más abierta y accesible a todos, más participativa y con más capacidad de reflejar las necesidades o preocupaciones de las distintas comunidades (Palacios, 2009).

En el caso de esta investigación nos centramos en dos comunidades muy concretas, la relativa a la infancia (niños/as de entre 5 y 6 años de edad) y por otro lado, la comunidad de la tercera edad (60 en adelante), por lo que el principal objetivo es conocer cuáles son las necesidades o preocupaciones de estas comunidades, algo que se verá con más detalle a lo largo del artículo.
Dada la relación existente entre el arte público, arte comunitario y artivismo, se propaga la idea de la obra como una localización concreta donde se debe tener en cuenta tanto sus dimensiones espaciales como físicas. Esto ayuda a comenzar a valorar el espacio usado como algo social y humano y no simplemente como un emplazamiento físico sin ningún sentido más allá. Tiempo atrás este arte estaba muy relacionado con los barrios más marginales y pobres y solía ser un arte creado por algún miembro de ese barrio que debido a su conocimiento de la problemática y a su compromiso social recreaba obras artísticas, como por ejemplo murales en zonas comunes. Un ejemplo sería el mural creado por Judy Baca, titulado "The Great Wall" ( Palacios, 2009).

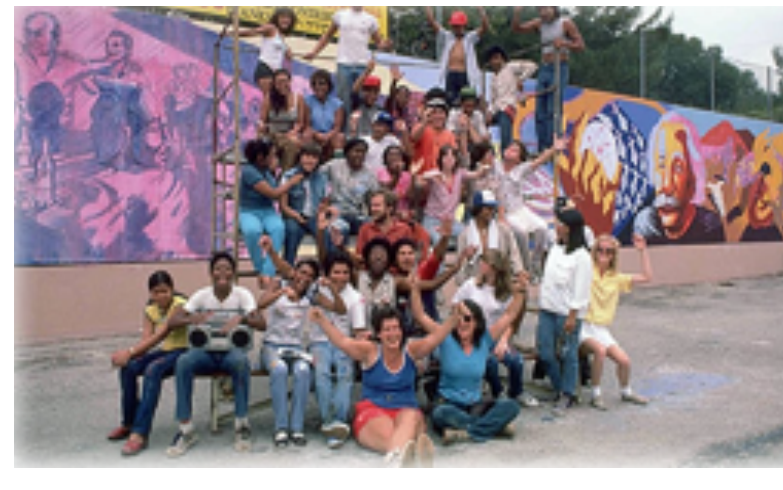

Imagen extraída de la red: http://sparcinla.org/the-great-wall-part-2/

Las prácticas comunitarias son desarrolladas en distintos ámbitos, como pueden ser hospitales, centros culturales, asociaciones de diferente índole o galerías de arte, entre otros lugares. Pero independientemente del lugar, hay algo seguro y muy concreto, el arte comunitario simboliza comunidad, y este término puede ser entendido como un grupo de personas que colaboran conjuntamente, que están unidas por experiencias o sucesos similares y que están involucradas de forma conjunta ante un tema concreto con vista de llevar a cabo un proceso creativo y grupal. Además, actualmente se entiende comunidad como un lugar físico que depende a su vez de las relaciones afectivas y emocionales para cobrar verdadero sentido (Palacios, 2009). 


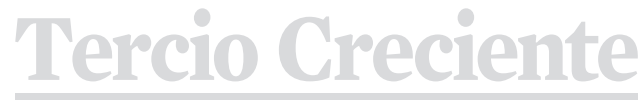

ISSN: 2340-9096

DOI: https://dx.doi.org/10.17561/rtc.n14.9
Investigación
Abad (2011) refiere que las acciones comunitarias artísticas que promueven una participación creativa y que usan el arte como generador de procesos que permitan cierta identificación con la vida, aprendizaje colectivo y afectividad grupal, son muy efectivas, pues conllevan reconocer la estética de las relaciones interpersonales, el diálogo grupal como mediador socio-cultural y una verdadera inclusión de todos los miembros participantes.

Dentro del término comunidad existen cuatro modelos bien diferenciados que según Miwon Kwon (como se citó en Palacios, 2009) son los siguientes:

- $\quad$ Categoría social: formada por inmigrantes latinoamericanos, mujeres...etc.

Grupo u organización asentado en un lugar: se trata de grupos concretos como podrían ser los trabajadores de una tienda o el alumnado de un instituto. El grupo concreto viene definido por la necesidad que tenga el artista de trabajar con un grupo u otro. Lo cual serían el ejemplo de las dos comunidades usadas en esta investigación, pues se han escogido concienzudamente a niños y ancianos.

- Comunidad creada especialmente para realizar una obra de arte concreta y que desaparece tras la realización de esta. Este tipo depende mucho del respaldo económico.

Comunidad que se crea para la realización de la obra pero que tras ella sigue existiendo como tal, debido en gran parte a que el artista forma parte de ella.

En esta visión de arte comunitario, es fundamental la participación grupal para poder llegar a una comunicación comprensiva entre el grupo, y que esto origine en consecuencia, la creación conjunta de una obra artística, donde se trate un tema social que afecta a estos. $Y$ fue esta la idea principal que me movió a llevar a cabo esta investigación artística, pues como docente de educación infantil creo con total convicción, que el arte no es solo una gran herramienta pedagógica en sí misma, sino que es a su vez un gran medio socializador y por ello puede resultar muy provechoso tanto en la infancia como en la vejez.

Estos procesos de creación grupal son realmente interesantes y satisfactorios, debido a los procesos de creación y experimentación que se originan tanto a nivel estético, como a nivel del fomento de la creatividad. Asimismo los procesos sociales y los procesos pedagógicos desarrollados durante la creación artística, promueven una comunicación afectiva y muy significativa entre los miembros del grupo (Toso,2009).

Una vez aclarado el significado del referente artístico que sustenta esta investigación pasaremos a hablar de los posibles beneficios que tiene el desarrollo de prácticas artísticas en el ámbito educativo y en la tercera edad (residencias o centros de día).

2.2 El valor de las prácticas artísticas para el alumnado de Educación Infantil

Es una realidad asumir que actualmente la educación artística en los colegios, especialmente en la etapa que nos incumbe, educación infantil, está relegada a cuatro momentos de ocio y entretenimiento para el alumnado, donde las tareas que se realizan en mayor medida, son manualidades y coloración de dibujos o fichas. Resulta evidente que el profesorado no conoce o no ha sido formado adecuadamente acerca de los cuantiosos beneficios que la realización de las prácticas artísticas pueden ocasionar en el alumnado. Un ejemplo muy sencillo en relación a la idea de educación artística que hasta el momento recrean los docentes de preescolar y es un hecho del que todos seguro hemos oído hablar o visto personalmente, son las típicas manualidades realizadas en los colegios para días festivos como el día de la familia, Navidad o Semana Santa. Resulta tremendamente llamativo observar como todo el alumnado sale del aula con la misma manualidad, los mismos colores, la misma forma y obviamente, la misma técnica. ¿Por qué no se les deja libertad de 


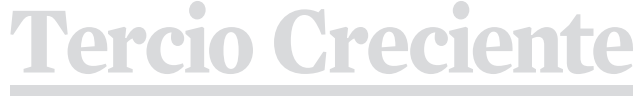

ISSN: 2340-9096

DOI: https://dx.doi.org/10.17561/rtc.n14.9
Revista de Estudios en Sociedad,

Artes y Gestión Cultural

www.terciocrecientecom

http://revistaselectronicas.ujaen.es/index.php/RTC expresión?, ¿por qué no damos rienda suelta a la creatividad y tomamos el papel docente como mero guía de esa práctica artística y no como instructor?, ¿no sería más enriquecedor conceder al alumnado la libertad de decidir que práctica artística le resulta más atrayente o significativa?, o ¿cómo le gustaría crear, con qué material, con qué colores...?. Este lastre que la educación artística sufre aun hoy en el siglo XXI en muchos colegios debe cambiar, y la principal idea sería reconocer que todos somos diferentes, con diferentes gustos y a su vez, con diferentes habilidades y así debe tenerse en cuenta. Eso por ende, nos hace también reflexionar sobre el pobre valor que se le da al arte en la sociedad en general.

Durante las prácticas docentes realizadas en mis años de estudio del grado en educación infantil, pude comprobar en primera persona todo lo argumentado aquí, aunque para mi grata sorpresa he de reconocer que existen algunos colegios (una minoría) que se muestran muy dispuestos a colaborar en las nuevas propuestas artísticas que los estudiantes de Educación Infantil proponen realizar en sus centros. Lo cual por mínimo que pudiera resultar ese porcentaje, supone una esperanza de mejora y lucha por una verdadera consciencia y reconocimiento de la relación entre arte y escuela.

Es aconsejable comenzar a introducir las artes desde temprana edad, debido a que es en estas edades cuando aún la mente es totalmente moldeable y receptiva ante cualquier situación o estímulo. Algunos autores avalan la importancia de la incorporación de las artes en el contexto educativo, como es el caso de Rudolf Arnheim (citado en Palacios, 2006) quien prestaba especial atención al sistema sensorial y perceptivo en la infancia, ya que el contemplaba los sentidos como la base en la que se desarrolla el sistema cognitivo y a su vez, entiende las prácticas artísticas como excelentes vías para el desarrollo de los sentidos. Además, Arnheim era defensor de que el ámbito escolar preste dedicación a la relación existente entre intelecto e intuición y considera el arte herramienta innata para fomentar la propia intuición humana.

En relación a lo comentado anteriormente, sobre la idea de que cada uno de nosotras/as poseemos distintas habilidades, resulta idóneo mencionar a Howard Gardner fundador de las inteligencias múltiples. Gardner demostró que cada uno de nosotros/as somos mejores en ciertas competencias y que el aprendizaje debería atender a dicha personalidad. El reconocimiento del predominio mayor de una inteligencia u otra en cada persona, sería la clave para otorgar una educación más justa y equilibrada, donde cada alumno/a tenga la oportunidad de desarrollar potencialmente sus propias habilidades artísticas, no olvidando que esto no significa que se deba solo potenciarse aquella inteligencia que nos sea más destacable a cada persona, sino llevar a cabo una enseñanza más individualizada (García, 2005).

Por otro lado, Howard Gardner además apostaba por la idea de que la cognición es la capacidad del ser humano para usar símbolos, lo cual va más allá del propio lenguaje verbal y la lógica. Atendiendo a esta idea, indicaba que la habilidad artística propia del ser humano se considera en sí misma una actividad mental y esta usa y modifica las clases de símbolos y sistemas simbólicos (Palacios, 2006).

También han prestado atención a la educación artística en el ámbito educativo otros autores que no son tan conocidos, pero que por ser educadores de arte y defender la idea planteada en este artículo merecen ser comentados: Jesualdo, Luis F. Iglesias y las hermanas Cossetini (como se citó en García ,2005) refieren el desarrollo de siguientes capacidades en el alumnado al realizar prácticas artísticas.

Por un lado, reseñan que el arte potencia el desarrollo de las capacidades sensitivas en el alumnado, las cuales les permiten conocer el mundo que les rodea, conocerse mejor a sí mismos y al 


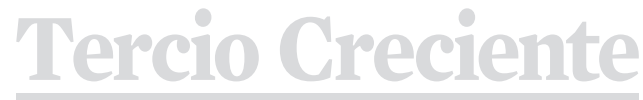

ISSN: 2340-9096

DOI: https://dx.doi.org/10.17561/rtc.n14.9
Investigación resto de compañeros/as. Esto es sin duda, uno de los principales objetivos de la educación infantil y así se recoge en el currículum de esta etapa.

También el arte ayuda al desarrollo y fomento de las capacidades cognitivas lógico-verbales, lo que permite al alumnado situaciones en las que se propicie la reflexión sobre los sucesos que se originan en el entorno y que estos a su vez, pueden servir de inspiración para la creación de prácticas artísticas en el aula, tanto propias como grupales. Además el arte potenciará el diálogo, pudiendo entablarse conversaciones sobre las prácticas artísticas realizadas o por realizar, haciendo uso del razonamiento o la valoración de lo pensado o plasmado.

Otra de las capacidades que comentan y quizás sea la más conocida por todos al hablar de arte, es el desarrollo de la capacidad creativa. Fomentar esta capacidad dará al alumnado claves para poder responder de forma original a las diferentes problemáticas sociales o naturales que en el día a día se les presenten al alumnado, lo que fomenta a su vez el pensamiento divergente.

En relación a las capacidad expresiva, el arte permite al alumnado que expresen libremente sus ideas, pensamientos o emociones, bien sea mediante el propio cuerpo, la expresión oral o la expresión plástica, entre otros modos, ya que las posibilidades del arte son numerosas. Todo ello ayudará además a la desinhibición del alumnado de manera lúdica. Podría resumirse indicando que:

Es relevante que la obra de arte se asocia de manera prioritaria a la comunicación y no al acto de expresión en sí, que no se limita al deseo de alguien de crear, de generar algo con respecto a él mismo. Cada ser humano, cada sujeto participa en una dinámica compleja, y todo acto que realiza, toda práctica significante que genera, también va a entrar en un conjunto de redes. (Radulescu,2012, p.27)
Mencionar además, que las capacidades prácticas también se ponen de manifiesto obviamente al desarrollar creaciones o expresiones artísticas y esto permite al alumnado desarrollar y fomentar la psicomotricidad gruesa y fina y conjuntamente, a la vez que contribuyen a crear a personas responsables y comprometidas socialmente.

Abad (2011) quien ha prestado especial atención al arte comunitario en contextos escolares, indica que el arte comunitario está tremendamente guiado por todos los procesos flexibles o perceptibles al cambio que existen en la vida común y que toman la propia vida personal de cada persona como guía para crear relaciones con el resto. Por lo que este tipo de arte comunitario, centra la "estética" en las relaciones personales que se originan, es entonces una estética basada en la negociación, dialogo grupal, intercambio cultural y confrontación de diversos puntos de vista y no únicamente, en el sentido puramente "bello" de una creación artística.

Estas acciones son propias de un modelo de escuela integrada y comprometida con la sociedad y que por tanto, crean ocasiones en las que se origine cierto intercambio o transformación de situaciones entre la propia escuela y el exterior. Pues ambos lugares se necesitan mutuamente y ser conscientes y participantes en la sociedad, ayudará al alumnado a sentirse respetados e implicados con sus iguales y su entorno.

La práctica que se propone en esta investigación combinará danza y artes plásticas, en concreto el dibujo libre, esta segunda en mayor medida y su fin primero será el de ayudar al alumnado a comunicar sus ideas y pensamientos de forma libre y creativa, por lo que la creación plástica en concreto, ayudará al alumnado a sentir la realidad social tanto a nivel interno como externo, percibir diferentes estímulos del entorno y de lo conversado con los compañeros/ as y elegir de manera personal como plasmar visualmente su ideas ante la problemática tratada (Pinedo,s.f). 
El dibujo espontáneo y la pintura permiten a los niños plasmar y exteriorizar sus ideas, sentimientos o emociones de forma más sencilla de lo que les resultaría hacerlo a estas edades mediante la palabra. Por ello, a través del dibujo obtendremos información que nos permitirá entender mejor su modo particular de habitar y entender el mundo (Romero, 2004).

Por todo lo comentado aquí y lo relativo al artivismo, resulta muy interesante y beneficioso llevar el arte al aula, no únicamente en momentos puntuales sino como medio integrado dentro de la propia metodología educativa diaria del aula.

Tras conocer, cuales son los beneficios para los niños/ as es necesario conocer también qué ventajas puede aportar a la tercera edad.

\subsection{Beneficios de las prácticas artísticas en la tercera} edad

La etapa de la vejez lleva implícito cierto deterioro físico y cognitivo, pero la mayoría de las personas conservan todas las neuronas cerebrales hasta la muerte, por lo que mantener el cerebro activo a estas edades ayudará a generar nuevos caminos neuronales. Es ahí donde las artes pueden ayudar no solo a la actividad mental sino a que sepan percibir y prestar atención a lo que oyen, ven, comentan o experimentan durante el desarrollo de creaciones artísticas (Carrascal y Solera,2014).

Zamarrón (citado en Carrascal y Solera, 2014) refiere que además estas prácticas artísticas poseen una metodología lúdica que permite a los participantes socializarse entre sí y fomentar la continuidad del desarrollo activo a nivel cognitivo, social y afectivo. En consecuencia, a promover mejor calidad de vida y una vejez sana.

Martínez y Gracia (como se citó en Olalla, 2010) argumentan que con la llegada de la vejez muchas personas comienzan a sentirse menos valoradas socialmente, pero también es importante reconocer que no todas las personas se enfrentan a esta nueva etapa de la misma forma y esto depende sustancialmente de la personalidad o su contexto sociocultural, lo que les hará responder de diferente forma a los distintos factores sociales, biológicos o psicológicos que pudieran surgirle.

De igual modo, indican que aun teniendo en cuenta las peculiaridades a nivel individual de cada persona en lo que respecta a la forma de asumir la etapa de la vejez, se debe ser consciente de que estas personas continúan teniendo ganas de conocer el mundo y explorar nuevas realidades y contextos que les permitan seguir viviendo activamente en la sociedad. El arte por tanto, podría servir de medio para explorar y crear esas nuevas experiencias, bien sea desde algo que no conocen o partiendo de lo ya vivido o conocido por ellos, para intentar transformarlo haciendo uso de las expresiones artísticas.

Debido a la relación existente entre el arte contemporáneo y la expresión sensitiva, a través de él podemos ayudar a las personas a generar una nueva visión de vida y fomentar el desarrollo de los sentidos, que a estas edades pueden verse más deteriorados. El arte es un buen medio para volver a equilibrar y dar cierto reconocimiento personal, así como valor social a las personas de la tercera edad y de manera especial, el arte artivista es una buen medio para ello. Uno de los principales beneficios que genera la realización de prácticas artísticas es el fomento de la creatividad, esto sucede en todos los seres humanos independientemente de la edad, pero si nos centramos en la tercera edad cabe destacar que según indicó Harvey Lehman (citado en Olalla, 2010) las personas que han fomentado su creatividad han tenido una vida más larga.

En el caso de esta investigación una de las finalidades es destacar aquello que preocupa a este colectivo respecto a las problemáticas sociales actuales, ya que considero que es desde su propio patrimonio personal y la propia vivencia desde donde podrán analizar y comparar los tiempos pasados con los actuales e identificar los posibles cambios y preocupaciones propias del siglo pasado y del presente. Y obviamente, será el sector de la 
tercera edad quien pueda contar desde su propia perspectiva ese cambio vivido y cuáles han podido ser los efectos provocados hasta el momento en la sociedad.

Así mismo, lo corrobora Olalla (2010) cuando indica: "que el interés por lo nuestro viene determinado por un sentimiento de propiedad" (p. 135). Con esto podemos referirnos a aquello que nos parece importante porque lo hemos vivenciado o sufrido de manera directa y que podemos querer conservar o en cambio, querer evitar o transformar por no estar de acuerdo.

\section{Acción descriptiva}

\subsection{Desarrollo metodológico}

La presente se trata de una investigación educativa de origen cualitativo basada en las artes (IBA), que a su vez posee estrecha relación con la investigación acción-participación (IAP). La elección de este tipo de metodologías se ha debido por un lado, a que se considera el arte como un medio eficaz para llevar a cabo una investigación educativa, en concreto la IBA. Según Mason y Sclater (citado en Hernández, 2008) al tener en cuenta el uso de dibujos o viñetas, ayuda a relacionar conceptos mentales o ideologías con situaciones reales concretas, al ejecutar componentes personales y colectivos de la propia experiencia cultural y social.

Por otro lado, también se ha tenido en cuenta el papel del docente como agente de cambio social, por lo que se considera que su labor va más allá de la simple gestión académica y así la elección de la investigación IBA parece ser una acertada decisión pues ayuda a promover la labor docente (tanto del educador infantil como del educador social) de formar a alumnado en la obtención de cierto compromiso social.

Además la IAP, también da cierta cuenta en esta investigación, como ya se ha comentado anteriormente, pues en ella se pretende provocar la reflexión sobre la realidad existente. Además de ello, se tiene en cuenta la acción-participación de las personas investigadas por resultar verdadera fuente de conocimiento e información y de esto modo se han tenido en cuenta a los propios participantes como verdaderos agentes transformadores de la sociedad (Ander-Egg, 2003).

El método usado es el arte, en concreto el diálogo grupal y la realización de un dibujo colectivo enmarcado dentro del artivismo. La técnica usada en esta investigación, será principalmente la observación directa, en la que para poder dar cuenta de todo lo surgido durante el desarrollo de la práctica artística, se ha hecho uso de una cámara fotográfica con la que se ha fotografiado y filmado algunos momentos de la investigación.

3.2 Contextualización de la práctica artística: lugar y participantes

Esta investigación ha sido llevada a cabo en el colegio concertado "Monseñor Miguel Castillejo. Fundación Vera-cruz" ubicado en Jaén capital. El alumnado con el que se ha desarrollado la investigación ha sido una de las clases de cinco años. Respecto al colectivo de la tercera edad ha sido puesta en práctica en la residencia de mayores Sebastián Estepa Llaurens "FOAM" también localizada en Jaén capital.

3.3 Desarrollo de la investigación y acciones a realizar en la práctica

La investigación presente tiene como objetivos acercar la práctica artística al alumnado de educación infantil y a un colectivo de personas de la tercera edad, así como analizar qué preocupaciones sociales presentan estas personas en el momento de realizar la investigación, para poder promover una perspectiva de mejora social. También se pretende conocer cuál es la reacción de las personas participantes al proponerles realizar este tipo de práctica artística, así como evaluar qué grado de implicación y participación presentan para detectar posibles diferencias entre un grupo y otro en relación al valor que le dan al arte. 
La práctica artística consta de varias partes, en primer lugar se iniciará el tema tratando de conocer cómo se sienten y que cosas les asustan o preocupan acerca de lo que estamos viviendo actualmente en la sociedad. La idea inicial es dejar total libertad de expresión, por lo que la acción de la investigadora es simplemente de guía, se dispondrá de varias imágenes en las cuales se reflejarán ciertas problemáticas sociales que puedan afectar al alumnado y a las personas de la tercera edad para que sirvan de ejemplo y precedente ante la idea de que nazcan nuevos temas, teniendo en cuenta su edad y su nivel de conocimiento social para elegir dichas imágenes. Así mismo la elección de estas imágenes servirá para transmitir a modo de ejemplo cuales son mis preocupaciones sociales como ciudadana e investigadora educativa.

Tras reflexionar y dialogar de forma conjunta sobre ciertas temáticas se propondrá realizar un dibujo colectivo sobre papel continuo haciendo uso de ceras y colores. La realización del dibujo, cuya temática se habrá decidido de forma consensuada el por los participantes, tiene cierta peculiaridad pues se trata de un "dibujo musical". El cual consiste en que se colocará en el suelo o mesa un trozo de papel continuo y las personas se colocarán alrededor de él, primeramente cada uno comenzará a dibujar su idea de cómo le gustaría cambiar esa problemática social y en un momento dado se procederá a poner música que será la señal de que tendrán que comenzar a moverse de forma libre alrededor del papel hasta que la música pare; cuando la música haya parado cada persona deberá continuar realizando el dibujo que tiene delante de él (el cual no será el suyo propio sino uno al azar en función del lugar donde haya parado tras moverse alrededor del papel). De esta forma el dibujo será completado gracias a la acción y participación grupal de todos.

\subsection{Desarrollo de las acciones realizadas ${ }^{1}$}

3.4.1 Práctica artística con el alumnado de 5 años de infantil

En primer lugar me dispuse a contactar con el colegio, en el cual ya había estado realizando mis prácticas docentes el año anterior, la coordinadora del ciclo de educación infantil enseguida se interesó por la propuesta y me indicó que no habría problema para llevarla a cabo pero que si se pretendía tomar imágenes deberíamos primeramente contactar con las familias del alumnado. Por lo que tras ello, enviamos autorizaciones a las familias explicando en qué consistía la práctica artística que se quería llevar a cabo. También me dirigí a hablar con la directora de la residencia, la cual me indicó que debería realizarlo con las personas del centro de día pues las que estaban internas en la residencia eran casi totalmente dependientes y no podrían colaborar de manera muy participativa en la práctica. De igual modo, se solicitó autorización para poder filmar todo aquello más significativo vivido en el encuentro. La práctica artística consistió en ambos casos en una sola sesión, pues el tiempo que me permitieron estar en el colegio y en la residencia era limitado, ya que disponían de más actividades programadas dentro de su rutina normal diaria.

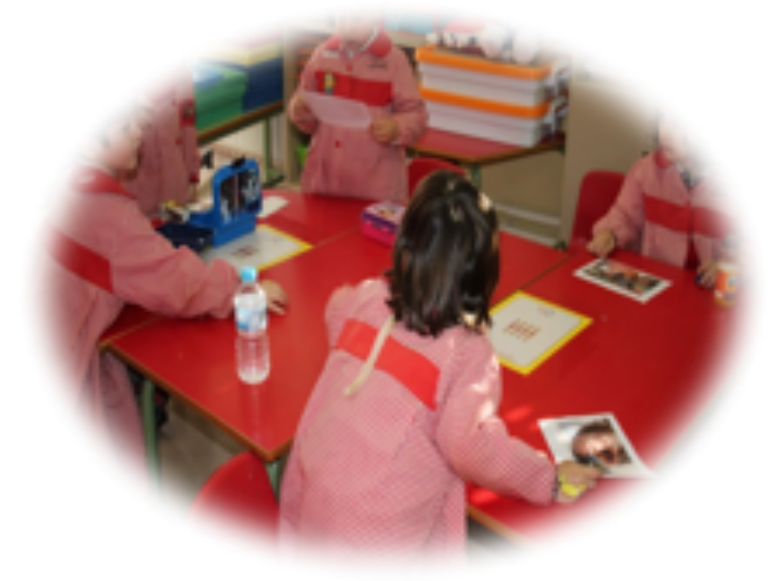

1.-Las imágenes del desarrollo de las acciones son de la autora 
A continuación, comenzaré analizando cómo transcurrió la práctica artística en el colegio, pues tuve ocasión de realizarlo con las dos aulas de cinco años por lo que la experiencia fue recreada y disfrutada doblemente. La primera toma de contacto consistió en conocernos, por lo que se llevó a cabo una dinámica de presentación grupal. Una vez conocidos los nombres de todos me dispuse a introducir el tema, contándoles que había algunas cosas que me entristecían y preocupaban enormemente. Para ello, me ayudé de fotografías con el fin de poder ilustrar mejor lo contado. En concreto, llevé cuatro fotografías relativas a: la pobreza infantil, la contaminación, el acoso escolar y la enfermedad. Entre todos fuimos visualizando cada una de las imágenes y contando que nos evocaba cada una de ellas, por lo que así conseguí adentrar al alumnado en la temática y comenzar hacerles reflexionar y dialogar sobre cosas que a veces nos pasan desapercibidas en el día a día, pero que realmente merecen urgentemente atención por parte de todos.

Partir de estas imágenes ayudó a que surgieran nuevos temas de preocupación para ellos/as, como la inquietud ante la presencia de comida que no les gusta (algunos alimentos comentados fueron el tomate, la cebolla), o la tristeza y miedo a la muerte, el cual me resultó sorprendente pues aunque es un preocupación social evidente, no es tan recurrente tenerla presente en la infancia. En la otra aula, donde también se llevó a cabo la propuesta, surgió el tema de la enfermedad antes de habérselo mostrado a ellos, por lo que entre todos concluimos que era un tema que no solo les preocupaba a ellos sino que a mí también.

Debido a que pesar de salir dos nuevas temáticas el alumnado comentó en mayor medida cosas relativas a su vida cotidiana y a los temas mostrados en las fotografías, opté por hacer uso de ellas durante la práctica.

Por ello, repartí a cada grupo de mesa las cuatro imágenes comentadas y les pedí que dialogaran y se pusieran de acuerdo en qué foto elegirían de esas cuatro, en función de cual les preocupara más, pues posteriormente dibujarían sobre dicho tema. Esta tarea al principio resultó algo ardua pues ponerse de acuerdo es algo que no suelen hacer y cada uno/a intentaba imponer su criterio, pero finalmente consiguieron entenderse y elegir una única foto por grupo. En la primera aula de los tres grupos de mesa que había, dos escogieron la fotografía relativa a la enfermedad y el tercero, como puede observarse en la imagen inferior, el tema del acoso escolar. En cambio, en la segunda aula, ningún grupo coincidió entre sí en la temática, ya que uno eligió el acoso escolar, otro la contaminación ambiental y el último, la pobreza en la infancia.

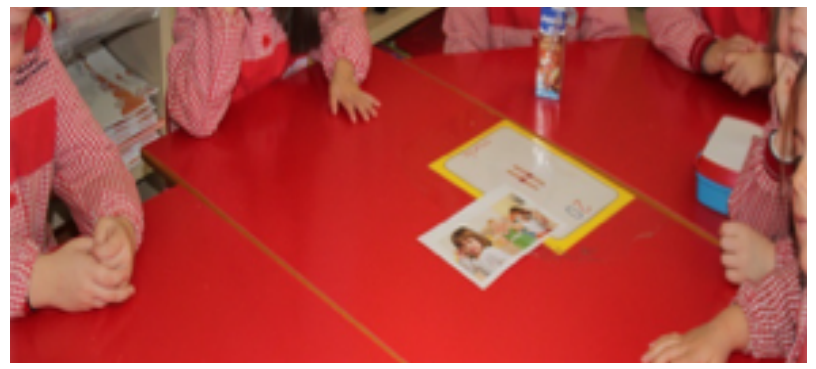

Una vez que todos los grupos habían elegido su temática, coloqué en el suelo tres trozos de papel continuo y ceras para cada grupo. El alumnado se colocó alrededor del papel y comenzó a dibujar libremente lo que les evocó esa imagen y la conversación entablada anteriormente sobre ella. No se dictó ninguna directriz salvo que recordarán cual era el tema en cuestión, pero en todo momento se dejó libertad tanto para el dialogo grupal mientras creaban su dibujo, como para realizarlo adoptando la posición que desearan, por lo que fue muy sorprendente ver como el alumnado se animaba al descubrir que podían tumbarse en el suelo libremente a dibujar lo que quisieran, lo cual no es algo muy habitual para ellos por las metodologías imperantes en gran parte de centros educativos.
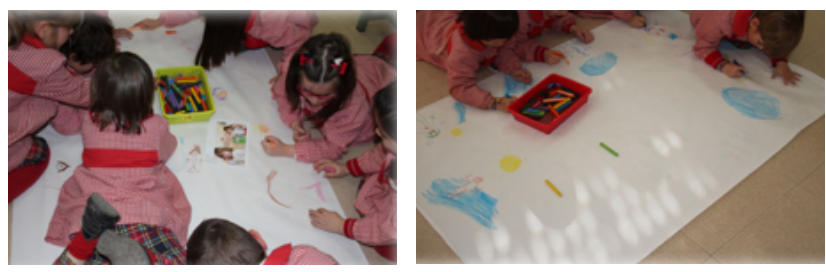
En un momento dado, se ponía música y el alumnado tenía que dejar de pintar para ponerse a danzar, moverse o desplazarse libremente al son de la música alrededor del papel continuo. Igual que en la creación del dibujo, tampoco se dio ninguna directriz y se les dejó expresarse libremente mediante su cuerpo, dejando brotar la alegría y efusividad propia del momento. Al pararse la música, cada uno/a debía detenerse en el lugar que estuviera y continuar dibujando aquello que tenía delante de sí, pudiendo coincidir que fuera su dibujo o en cambio, que fuera el de algún compañero/a y tuviera que observar lo que tenía delante y pensar sobre qué había dibujado y cómo podría continuarlo.

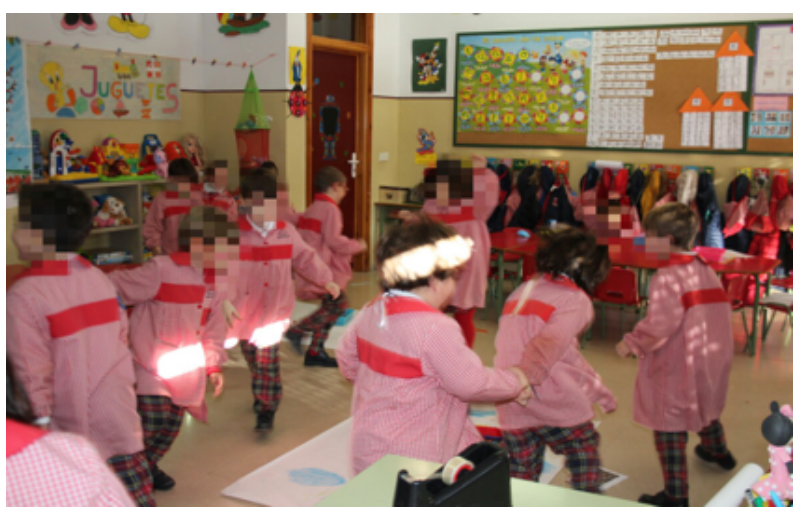

En la primera aula pude comprobar que en la primera parada de la música el alumnado intentaba volver forzosamente a su sitio para terminar su obra y en cambio, en la segunda se dejaron llevar libremente y se adaptaron al dibujo que les había tocado a pesar de no ser el suyo y a su vez, completaron este dibujo sin problema. Por otro lado, en la segunda aula donde se realizó la práctica, el alumnado respondió en ambas paradas de la música de forma correcta y no intentaban volver a lo suyo sino que les resultaba además gracioso tener que visualizar, entender y completar el dibujo que otro compañero/a había creado. Por lo que todos de forma colaborativa dieron origen a varios dibujos colectivos donde se plasmaron diferentes temáticas grupales que preocupaban a estos niños/as y que sin duda alguna son por el momento problemáticas sociales que a todos nos incumben en mayor o menor medida.

Aunque la finalidad principal de esta investigación no era el resultado plasmado en los dibujos sino que estos eran una forma de representar esas preocupaciones, haremos un breve análisis de algunas de las creaciones surgidas. En general, la participación del alumnado fue excelente y acogieron la práctica con total entusiasmo y ganas por colaborar y dialogar conjuntamente. Cabe destacar que la profesora del aula me comentó que hasta el momento no habían vivido ninguna experiencia similar, por lo que la reacción fue totalmente transparente e inesperada.

A continuación, puede observarse una imagen del alumnado creando su obra y de su resultado final sobre la temática de la contaminación ambiental.

En la imagen puede visualizarse como el alumnado había rotado de forma correcta y por ello, algunos dibujos quedaban ya terminados, mientras que otros en cambio, seguían formando parte del proceso de expresión-creación colectivo del alumnado.

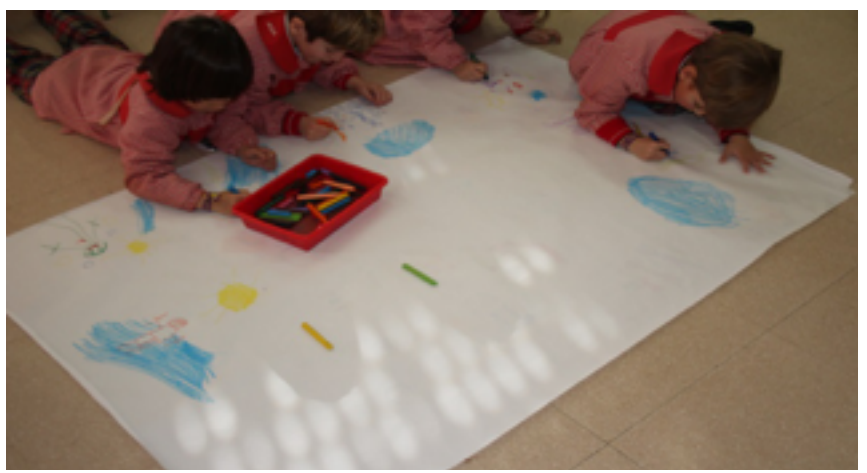




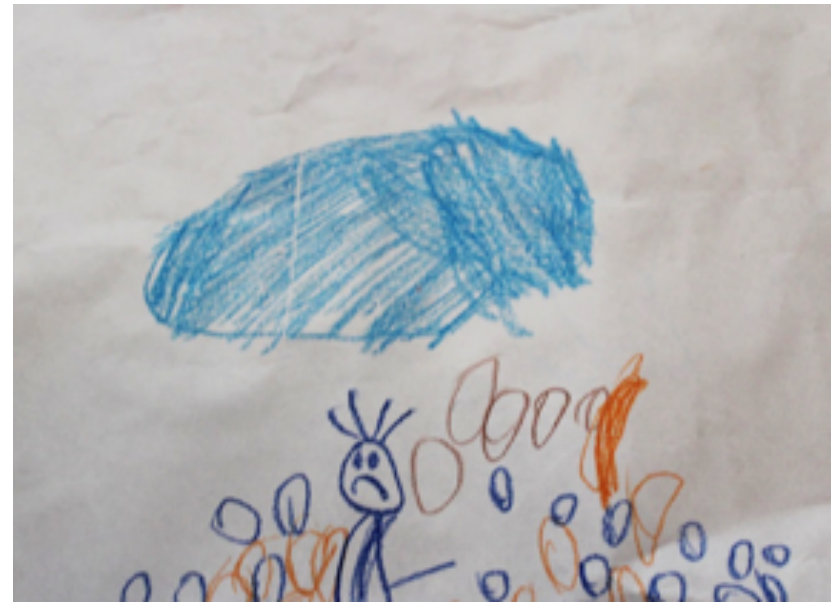

El dibujo mostrado en la parte superior, hace referencia tal y como me indicó el alumno, a que el hecho de encontrarnos basura en la playa, parque o piscinas es algo que le preocupa porque no puede jugar, ni divertirse, por ello el gesto del muñeco muestra una mueca triste al estar rodeado de círculos que bajo su particular interpretación simbolizan bolsas de basura de diferentes tamaños. El agua en cambio, la dibuja separada y totalmente limpia, pues es así como desearía y debería encontrarse la playa en verano.

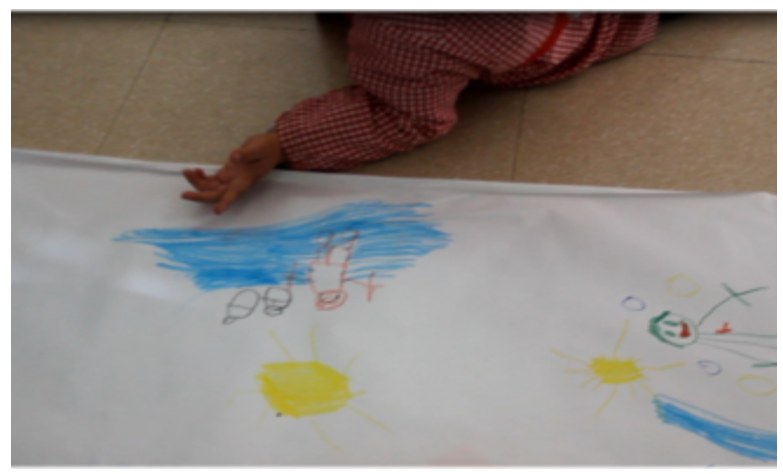

Este otro dibujo señalado por la mano del alumno, vuelve hacer referencia al descontento por encontrar el agua sucia y por ello, dibujó todo junto. En cambio, si observamos el dibujo ubicado más a la derecha en la imagen, se ve a una persona sonriente, basura a su alrededor y agua limpia. El alumno comentó que la persona estaba sonriente porque la basura iba a ser recogida y no ensuciaba el agua.

A continuación, una de las obras creadas en relación a la pobreza infantil.

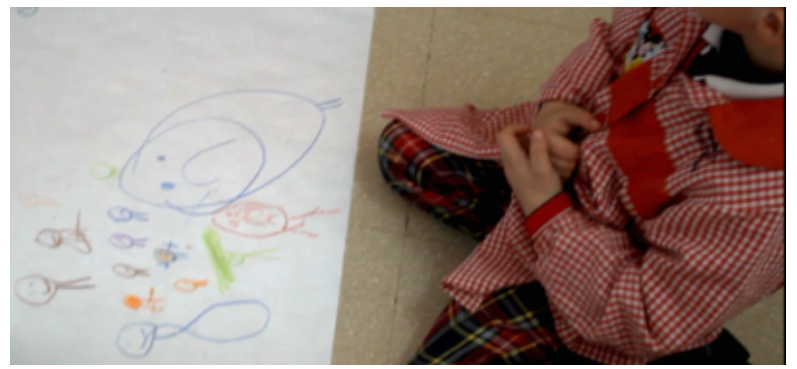

El alumno comentó que había dibujado a muchos bebés sin comida que se encontraban tristes y que algunos de ellos estaban muertos por no haber podido comer.

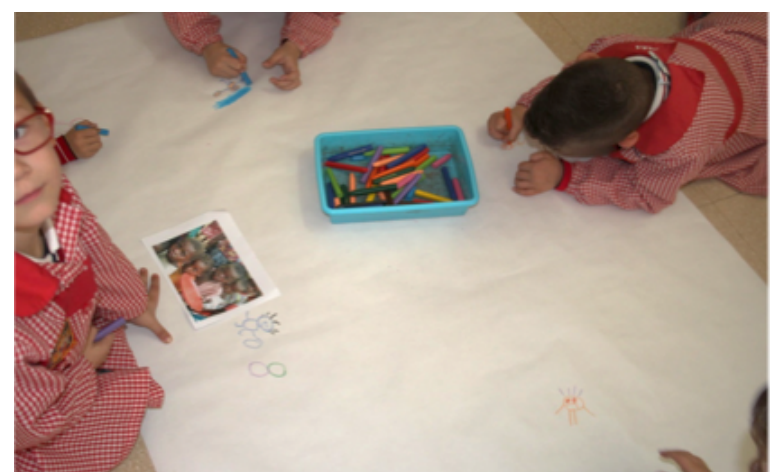


La temática del acoso escolar fue elegida por dos grupos y algunos de los resultados fueron los siguientes. En la imagen, puede observarse una situación muy común en cualquier parque o espacio de ocio infantil, tal y como me comentaba su creadora, una cosa que preocupa a los niños/a de esta edad es el hecho de que se les prive de usar el tobogán o los columpios, especialmente lo sufren cuando esto sucede por parte de niños/as más mayores que ellos, ante los cuales, me comentaron, se sienten atemorizados. Así en la imagen puede observarse como hay un niño dibujado a tamaño más grande, el cual se dispone a usar el tobogán y más atrás, un niño más pequeño tachado. Ese tachón puede simbolizar esa poca seguridad y ese sentimiento de tristeza provocado ante tales situaciones.

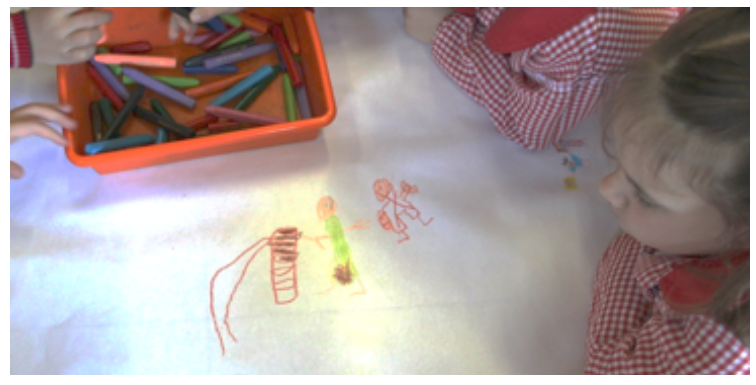

Encontramos también dibujos referentes a burlas y enfados que son sufridos por muchos niños/as en la infancia.

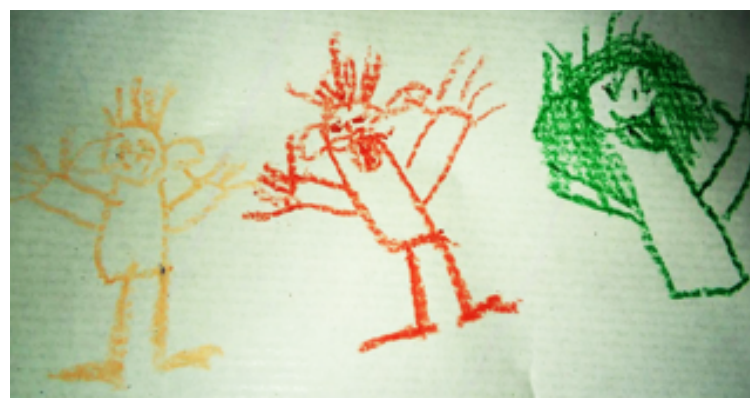

De la misma manera, hubo muchos alumnos/as que se decantaron por centrarse en la representación de la tristeza mediante el dibujo de caras alusivas a ello, como son los siguientes (ubicados más abajo). De igual modo, a pesar de ser todos dibujos referentes a caras tristes puede observarse la diversidad en su creación, pues es creación propia de cada alumno/a, con los colores que libremente han decidido y sin seguir ninguna directriz, por lo que la riqueza de estos dibujos está en gran media en sus particulares diferencias.

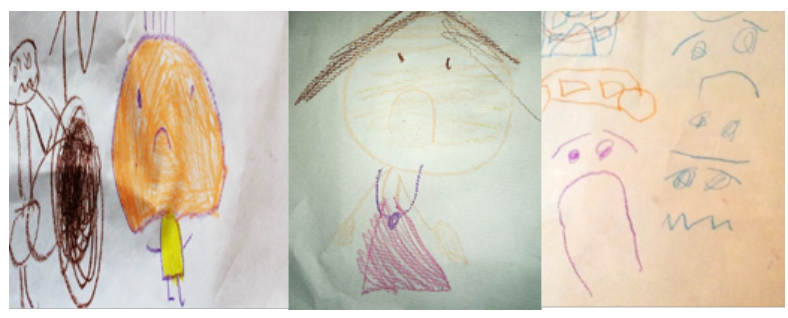

En relación también a la temática del acoso escolar, me parece interesante dejar plasmada la siguiente creación de Alejandra, donde me sorprende gratamente la creatividad propia de la infancia. Podemos observar como ha recreado una carita triste con lágrimas, la cual difiere mucho del resto de caras creadas por otros alumnos, por lo que ha llamado especialmente mi atención. A su vez, se encuentra una casa y una niña triste, que da lugar a cuestionar sobre si esta niña puede encontrar algún factor que le preocupe u ocasione malestar en su hogar, o si en cambio su casa forma parte del lugar que le sirve como escape. Lo cual desafortunadamente no pude saberlo, pues debido a la escasez de tiempo, se hacía prácticamente imposible analizar y comentar con detalle el dibujo de cada niño/a. Por lo que esta investigación, podría a su vez derivar en otra sesión que permitiese hablar de forma más distendida sobre las creaciones de cada uno/a, ya que aunque se hizo, no pudo dedicársele el tiempo oportuno. 


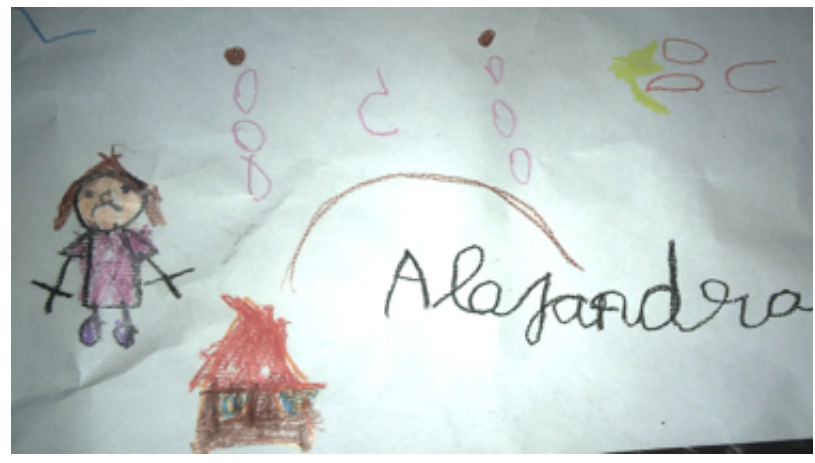

Por último, comentar lo producido acerca de la preocupación por la enfermedad tanto de familiares como amigos/as o personas conocidas por el alumnado. En general, en las producciones sobre esta preocupación, el alumnado comentó que había dibujado a gente que había muerto por estar "malita", incluso un alumno comentó, que había dibujado a un robot que estaba enfermo, lo cual me resultó bastaste curioso. En la imagen puede observarse como aparece gente llorando o gente tumbada en una cama, relativa a la relación que hacen entre estar malos y estar metidos en la cama para mejorarse. Alguna alumna incluso comentó lo aburrida y dura que es la estancia en los hospitales.

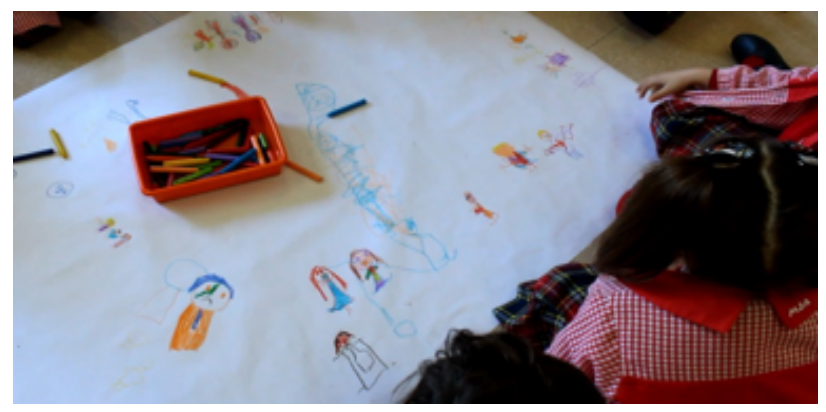

3.4.2 Práctica artística con las personas del centro de día de una residencia.:

Al llegar a la residencia me encontré con la animadora social y la psicóloga, las cuales estuvieron presentes como apoyo durante la realización de la propuesta. Mi sorpresa al llegar a la residencia fue encontrarme únicamente con un grupo formado íntegramente por mujeres, en la sala había también un hombre pero se mantenía al margen dormido en una silla. Posteriormente, se acercó a ver que hacíamos otro señor, pero muy reacio ante la práctica artística decidió observar pero no participar, indicando que era cosa de mujeres. Tras mi sorpresa, pregunté a la animadora y a la psicóloga por qué únicamente había mujeres, ante lo que me respondieron que las mujeres son las más dispuestas a realizar actividades de este tipo y que los hombres, prefieren mantenerse al margen descansando y viendo la tele. Información que me pareció muy relevante, pues nada más llegar ya obtuve información acerca de cómo los hombres de la tercera edad visualizan este tipo de prácticas artísticas y en general, otras actividades de ocio y expresión grupal. Obtenemos aquí un gran ejemplo de sesgo de género en ciertas actividades.

Al llegar allí, había mujeres que estaban coloreando, otras manipulando y contando garbanzos y otras en cambio, solo miraban. Al presentarme, la animadora dio la orden de recoger todo y algunas se mostraron reacias a dejar su actividad para comenzar con la dinámica en cuestión. Lo que me dio a entender, que o bien no se mostraban demasiado encantadas con la idea o que en cambio, no le habían comunicado que iban a llevar a la acción una práctica artística con una alumna de la universidad.

En primer lugar, me presenté al grupo y les dije de donde venía y lo que íbamos a hacer en ese rato juntas. Tras ello, cada una se presentó para poder conocerlas 
mejor y tener una breve toma de contacto inicial con el grupo, tal como puede verse en la posterior imagen presentada.

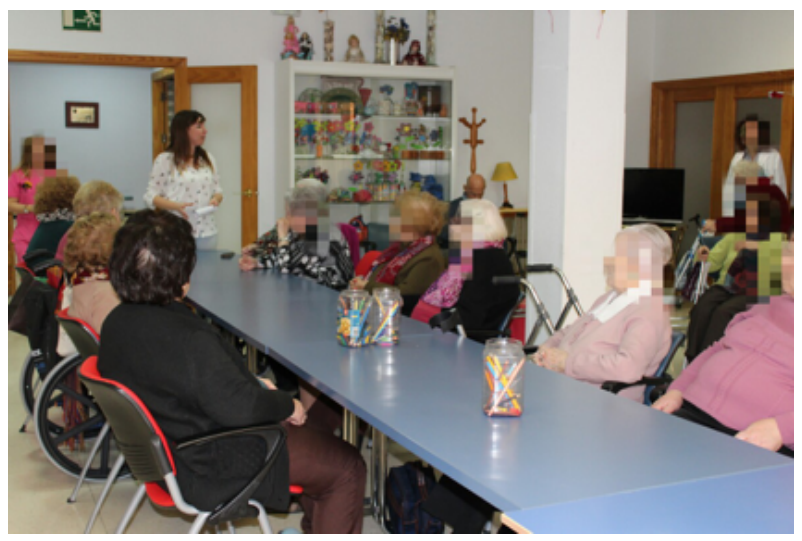

Una vez realizada la dinámica de presentación, comencé enseñándoles una imagen que plasmaba la fachada de una oficina de desempleo y un montón de jóvenes haciendo cola para entrar en ella. Este fue el punto de partida, por lo que les indique que lo que veían en la imagen era algo que a mí me preocupaba en exceso y como a mí, a un montón de jóvenes más. Les pregunté ¿qué era lo que veían? y tras varias interpretaciones erróneas, pues creían que yo era trabajadora de una oficina de desempleo, llegamos de forma colectiva a la preocupación que yo les pretendía transmitir, el desempleo en los jóvenes.

Las intervenciones fueron en mayor medida por dos de las mujeres allí presentes, mientras que las otras asentían con la cabeza pero no participaban y algunas ni si quieran miraban o mostraban atención a lo que allí estaba aconteciendo.

Tras ver esta poca participación, decidí insistir con otro ejemplo de preocupación social para de este modo animarles a participar y reflexionar, a la vez que permitía que me conocieran un poco más, pues como bien les indiqué esa imagen era algo que de forma personal a mí me preocupaba especialmente. En esta ocasión, les mostré una imagen donde se veía como un hombre robaba a otro la cartera sin que este primero se diera cuenta. Igualmente, tras ello volví a preguntar si sabían qué era lo que veían en la imagen y se la pasé para que pudieran verla mejor. Tras varias interpretaciones (terrorismo, un hombre que apunta a otro con una pistola) concluyeron en que se trataba de un robo. Y en esta ocasión, pude observar más participación y más desinhibición, lo que provocó un diálogo más fluido, pues enseguida comenzaron a comentar ejemplos de robos que habían vivenciado personalmente o que conocían por medio de otras amigas o por la televisión. Así concluimos en que el robo era un tema que a ellas también les preocupaba profundamente y más debido a que muchas de ellas vivían solas en casa. Además la animadora intervino para indicarme que allí en la residencia ya se habían encargado de dar algunas indicaciones acerca de cómo deben actuar y de las precauciones que deben tener para evitar ser víctimas de robos.

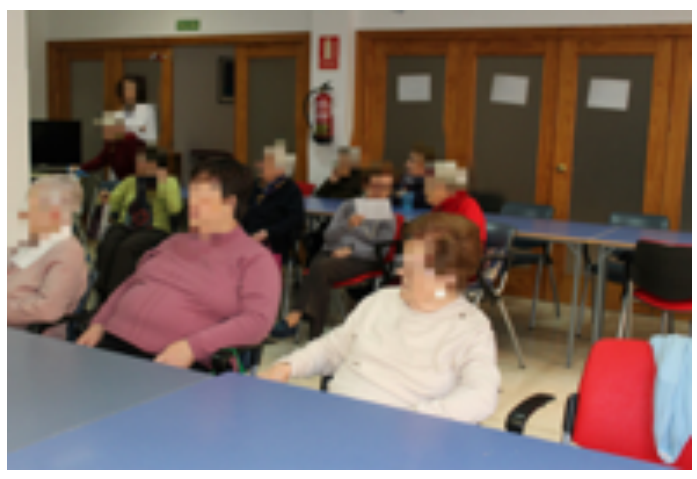

Después de toda la conversación surgida acerca del tema del robo, volví a insistir en que me contaran algo que a ellas les preocupase y ahí sí que surgieron varios temas, como el de la pérdida de salud. Una de ellas, comentó que le preocupaba mucho estar perdiendo visión, por lo que cada vez se veía más incapacitada y menos feliz. Tras esta intervención, las demás también afirmaron que era algo que les preocupaba a todas. 
Otra preocupación social que presentaban estas mujeres de la tercera edad y la cual no esperaba encontrarme, era la poca seguridad que tienen hoy en día los jóvenes al salir de fiesta en la noche, pues se encuentran expuestos a alcohol y drogas de forma habitual. De igual modo, les preocupaba todas las muertes y desapariciones de jóvenes que están sucediendo actualmente, más en concreto desapariciones de chicas. Por lo que la mujer que intervino alegaba que echaba en falta más presencia policial en las calles durante la noche.

Tras el dialogo, les indiqué que debían ponerse de acuerdo sobre un tema, el que más les preocupase de todos los comentados, pues íbamos a plasmarlo de forma grupal en un dibujo. El tema elegido fue el robo, pues varias de ellas habían sufrido en primera persona dichos atracos y se sentían muy indefensas e indignadas ante ello.

Una vez decidido el tema, coloqué papel continuo en ambas mesas (se encontraban sentadas en dos mesas, por lo que había dos grupos). La idea era la misma que con el alumnado de infantil, pero me comentaron que a pesar de que no todas disponían de silla de ruedas o andador, era prácticamente imposible pedirles que se levantaran para andar alrededor de la mesa. Pensé entonces en girar el papel cuando pusiera la música y así adaptar la actividad al grupo.

Una vez repartido el material, les indiqué que podían dibujar libremente aquello que quisieran en relación al tema acordado y fue entonces cuando encontré muchas negativas. Algunas ni siquiera intentaron dibujar algo, ya que se veían muy inseguras indicándome que nunca habían ido a la escuela y que no sabían dibujar, ni escribir. Yo las animé haciéndoles ver que no importaba que el resultado fuera mejor o peor sino que lo importante era intentar plasmar su reflexión sobre el tema de la forma que cada una pudiera y quisiera, pero finalmente muchas de ellas se negaron completamente a participar en la propuesta. Otras en cambio, lo intentaron pero debido a la falta de visión indicaban que no podían dibujar bien y también su papel fue el de observación, tal y como puede observarse en la imagen posterior.

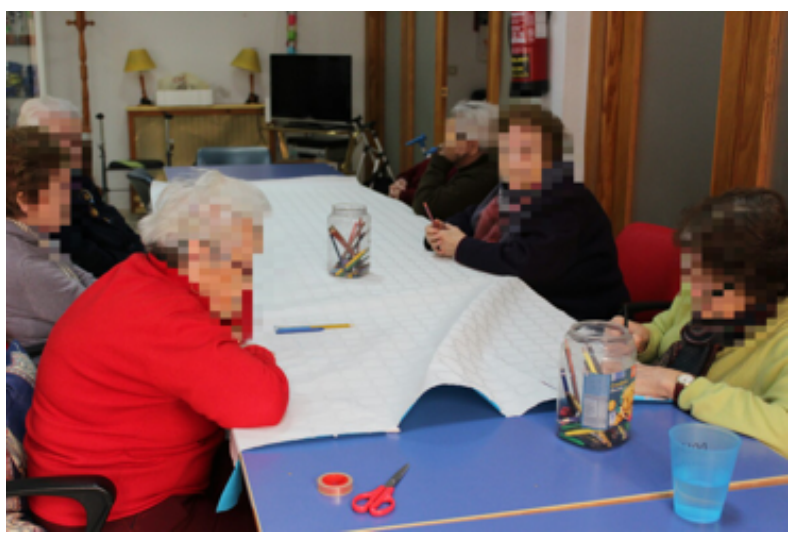

Algunas sí que alegremente se animaron ante la idea de dibujar acerca de lo acordado y tras ello, me comentaban que significaba lo que habían dibujado o escrito. Algunos de los momentos fotografiados fueron los siguientes.

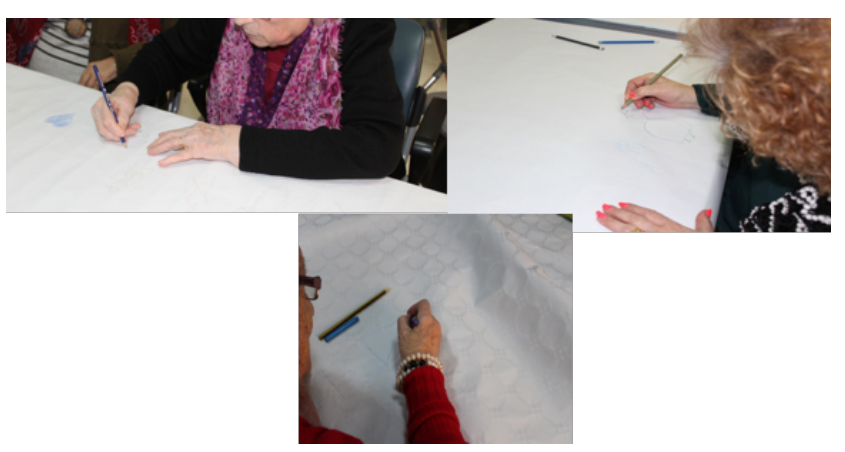

Al ver tan poca participación, decidí abortar la idea de girar el papel al poner música y en cambio, puse música durante todo el proceso para ambientar la práctica y cada una dibujo únicamente lo que ella quiso en relación al tema del robo/atraco. Algunas de las producciones son las a continuación expuestas. 


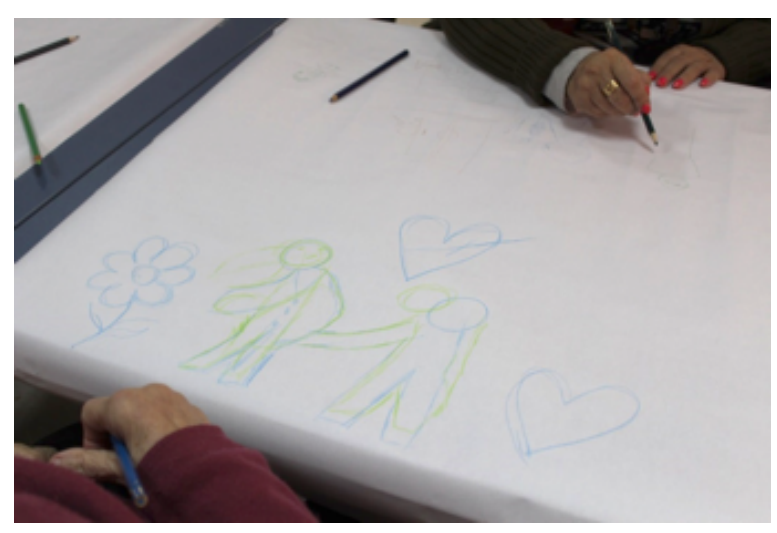

En esta primera imagen donde priman colores verdes y azules se observa como esta mujer recreó lo visto en la imagen que yo les mostré, pero añadió corazones y flores pues indicaba que la sociedad necesitaba de amor y más humildad para evitar estos casos de robos.

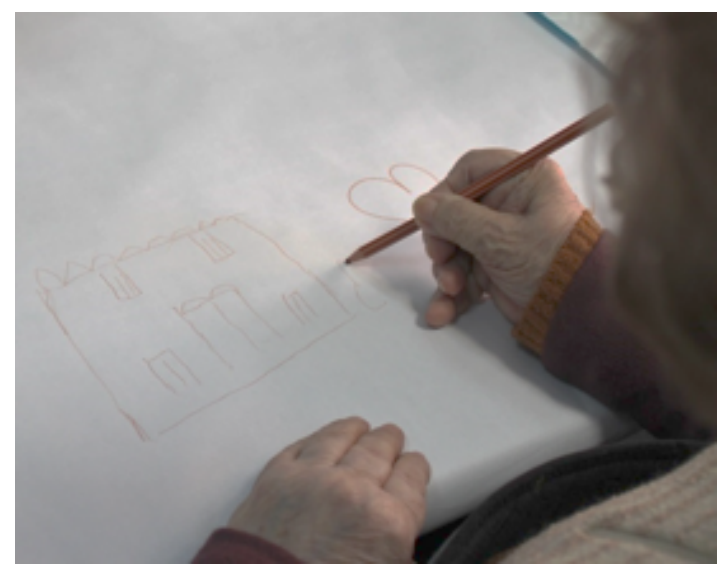

En la imagen arriba mostrada, puede verse como en este caso la preocupación se centraba en los robos en el hogar, por lo que ha dibujado una casa. La mujer comentaba que había sido víctima de un intento de engaño por unos supuestos trabajadores de una compañía de gas, que luego resultaron ser timadores.

Para concluir, es oportuno incluir una imagen que no hace referencia expresa al tema elegido de forma grupal, sino que se centró en una preocupación personal que presentaba una de las mujeres. Ella me contó que lo que había dibujado hacía referencia a un intento de secuestro que había presenciado cuando era más joven, pues habían intentado secuestrar a su hija, pero afortunadamente todo quedó en un gran susto.

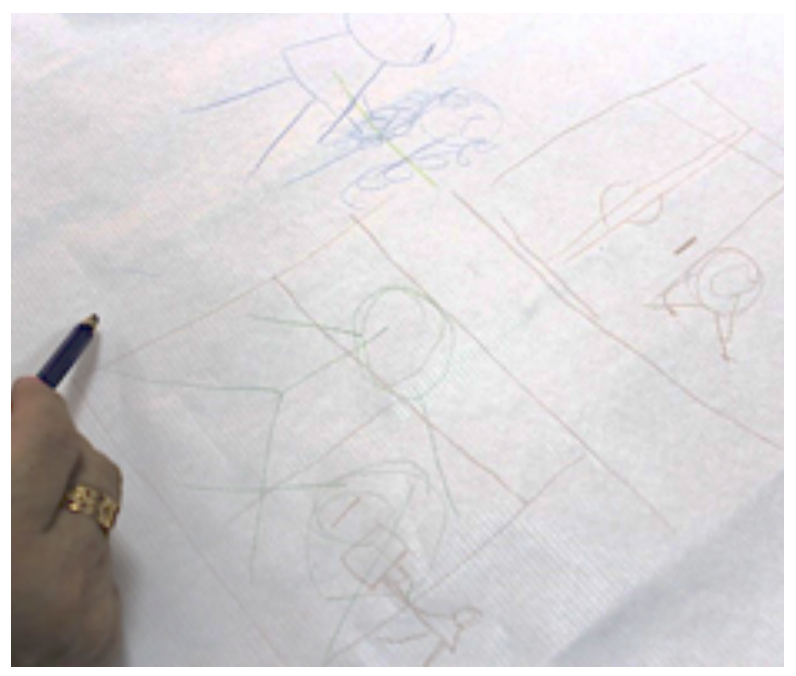

Aunque la participación fue más pobre de lo que esperaba inicialmente, me alegró enormemente poder compartir con ellas este momento y resultó una experiencia a la vez interesante y emocionante para ambas partes. Así se pudo comprobar en la expresión que mostraban aquellas mujeres que se involucraron y tomaron parte de todo lo vivenciado allí y prueba de ello es la imagen posterior, donde fue la propia mujer quien con una gran sonrisa me indicó que quería ser fotografiada mientras realizaba la práctica. 
En la imagen de grupo, puede comprobarse como se dedicó tiempo (al igual que con el alumnado de infantil) a dialogar con cada una sobre lo que habían creado, para posteriormente contárselo al resto de compañeras del grupo.

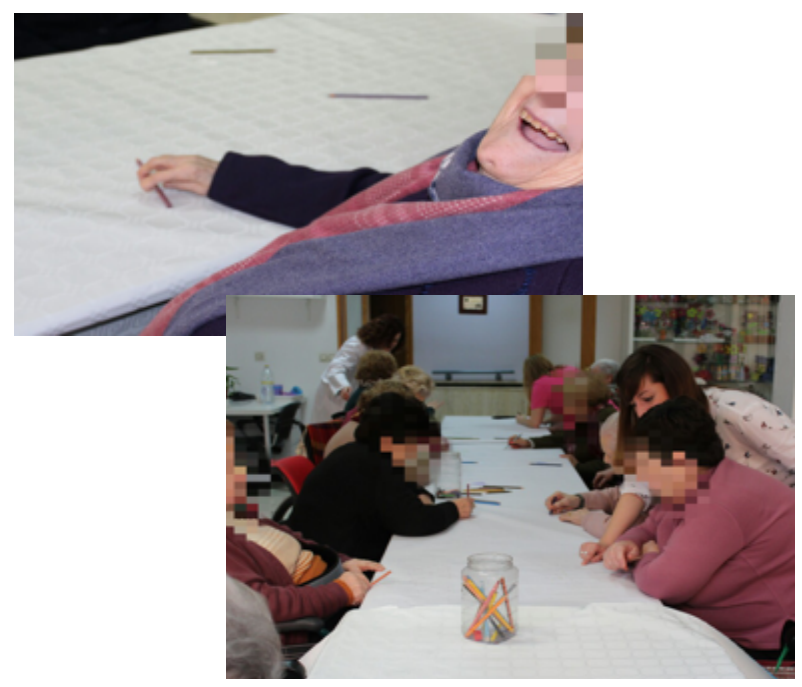

\section{Análisis y resultados obtenidos::}

Los resultados de esta investigación ha sido descritos y manifestados a lo largo del desarrollo de la propuesta artística, pues en la investigación educativa basada en las artes y en la investigación acciónparticipación, lo verdaderamente relevante, como ya se comentó, no es el resultado final únicamente sino el propio desarrollo y la acción que ha dado origen a todo ese proceso. Por lo que las deducciones y narraciones de todo lo vivenciado tanto en el colegio como en la residencia, dan por sí mismo gran respuesta a la hipótesis planteada en esta investigación.

El uso del arte como método para conocer y expresar las preocupaciones sociales propias de la infancia y la tercera edad, resultó una vía satisfactoria principalmente en educación infantil. La respuesta del alumnado fue excelente y a pesar del espacio tan poco apto que presentaba el aula para la realización de la práctica, por la distribución del mobiliario, ésta pudo llevarse a cabo de forma óptima y el alumnado uso el arte plástico como vía para dar salida a sus preocupaciones personales y sociales.

En cambio, con la tercera edad el uso del dibujo artístico como vía de expresión y reivindicación social no ha resultado del todo eficaz, siendo esto en gran parte debido a la falta de contacto que la tercera edad ha tenido y tiene con el mundo artístico. Esto pone de manifiesto la necesidad de prestar más atención a este ámbito en la tercera edad, pues ya quedó a lo largo del artículo demostrado los diversos beneficios que sus prácticas revierten en estas personas.

Así mismo, los resultados obtenidos en lo que respecta a los temas de preocupación social de cada colectivo, son puntos de partida que permitirían seguir trabajando con ellos dichas temáticas. En el caso de infantil, la enfermedad y el acaso escolar fueron los más repetidos, pero no por ello los más importantes, por lo que esta práctica puede servir para fomentar, trabajar y concienciar al alumnado sobre la necesidad de hacer frente y tomar conciencia social ante estas problemáticas, lo que sin lugar a dudas sería un pequeño paso hacia lograr una sociedad más libre, justa y equilibrada. De igual modo, podría profundizarse más detalladamente en todos aquellos temas que el alumnado comentó que les preocupaban, pero debido a la breve franja horaria de la que se dispuso para realizar la práctica todo fue realizado a un ritmo más rápido del que hubiese sido el ideal para poder dejarles más margen de pensamiento y reflexión. Y a su vez, hubiese sido idóneo haber prescindido de algunas de las imágenes de referencia mostradas para guiar la práctica, lo que posiblemente habría sido más fructífero al realizarse en una sesión más larga o incluso en varias de ellas.

Por otro lado, el tema que más preocupaba a la 


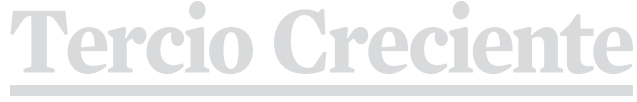

ISSN: 2340-9096

DOI: https://dx.doi.org/10.17561/rtc.n14.9
Revista de Estudios en Sociedad,

Artes y Gestión Cultural

www.terciocreciente.com

http://revistaselectronicas.ujaen.es/index.php/RTC tercera edad era el de los robos y atracos, debido sustancialmente a que es en esta edad cuando más vulnerables y expuestos se muestran ante estos sucesos. A fin de evitar y cambiar estas horribles situaciones a las que se ven expuestos muchos de nuestros mayores, podría ser eficaz crear más dinámicas que permitan darle herramientas y orientaciones que sirvan para prevenir estos atracos.

Por ello, también esta práctica artivista comunitaria es fácilmente integrable dentro del propio currículum escolar (en cualquiera de los diferentes niveles educativos) debido a que los objetivos y contenidos que se plantean en ella, son sin lugar a duda parte de las áreas de conocimiento de educación infantil. También es propio de la vida cotidiana de todos, por lo que esta práctica tiene oportunidad de llevarse a cabo con cualquier grupo social pues todos vivimos y sufrimos las problemáticas de la humanidad. Y de igual modo, todos mostramos y necesitamos la oportunidad de sentir y expresar libremente todo aquello que concebimos en nuestro yo más interior y que necesita ser compartido y reflexionado.

\section{Conclusiones:}

Tras analizar los resultados obtenidos en esta investigación, es coherente indicar que la investigación educativa artística es totalmente útil para investigar acerca de temas sociales y educativos, dadas sus características.

Este tipo de investigaciones permiten fácilmente conectar a las personas con su propia historia de vida, con los problemas cotidianos, con los que afectan de forma grupal y con aquellos más personales. A su vez estas investigaciones permiten buscar de forma conjunta el motivo de estas problemáticas, así como posibles vías de solución a estas. Es desde la propia sociedad desde donde deben buscarse y detectarse los problemas sociales y atender a ellos en la mayor brevedad posible, pues solo de este modo podremos ir labrando una sociedad más concienciada y justa al respecto.

Así mismo, comenzar a educar a la infancia en el medio artístico como vía idónea para expresarse y relacionarse con el resto, concluirá a largo plazo en unos ciudadanos abiertos al arte contemporáneo y al cambio social. Y de igual modo, poder poner en contacto a la tercera edad con estas prácticas contemporáneas les permitirá observar y analizar los cambios que se están vivenciando actualmente y les dará una visión muy distinta del arte a la que ellos tienen, pues únicamente conocen el "arte tradicional", el arte ligado a la belleza y la simple admiración o exposición en lugares totalmente encasillados.

Este cambio social, no puede producirse de forma inmediata, ni únicamente con haber realizado esta investigación, pero parece que podría resultar efectivo si este tipo de prácticas se desarrollasen de forma habitual. En cambio, sí que se han demostrado beneficios directos al realizar la práctica, en referencia a las relaciones interpersonales, el desarrollo de la creatividad e imaginación, fomento de la psicomotricidad y la reflexión grupal e individual.

No obstante, esta investigación podría continuarse ampliando la práctica artística a otros colectivos para obtener más información al respecto. 0 también volviendo a realizar otras prácticas artísticas con estos mismos colectivos, a fin de seguir investigando e intentando buscar las vías más oportunas para conocer y buscar el cambio en ciertos aspectos de la sociedad actual. Además considero que sería interesante plantear otro tipo de actividad artística con la tercera edad para tratar el mismo tema planteado en la investigación, pero haciendo uso de otros medios con el fin de comprobar si pudieran hallarse otra vía más satisfactoria y adecuada para conseguir el fin deseado con este colectivo. 


\section{Referencias}

Abad Molina, J. (2011). Experiencia estética y arte de participación: juego, símbolo y celebración. Recuperado de: http://www.oei.es/historico/artistica/articulos01.htm

Ander-Egg ,E. (2003). Repensando la investigación-acción-participativa. Recuperado de: https://s3.amazonaws. com/academia.edu.documents/34317063/REPENSANDO_LA_IAP.ANDER-EGG.pdf?AWSAccessKeyId=AKIAIW OWYYGZ2Y53UL3A\&Expires=1516043067\&Signature=J9hP9MUqHvWAHLGCcN\%2FCLkMUrn0\%3D\&respon se-content-disposition=inline\%3B\%20filename\%3DRepensando_la_Investigacion-Accion_Parti.pdf

Delgado, M. (2013).Artivismo y pospolítica. Sobre la estetización de las luchas sociales en contextos urbanos. Quaderns-e. Institut Catalá d'Antropologia, 18(2), pp.68-80. Recuperado de: file:///C:/Users/DEBORAH/ Downloads/274290-374469-1-SM\%20(2).pdf

García, S.A.S. ( 2 de Noviembre de 2005). Enseñanza y aprendizaje en la educación artística. El artista, (2), pp.8097.

Hernández, F. (2008). La investigación basada en las artes. Propuesta para repensar la investigación en educación. Educatio Siglo XXI, (26),85-118.

Martín, J.(2015). V CONGRESO INTERNACIONAL DE EDUCACIÓN ARTÍSTICA Y VISUAL. Sobre artivismo \{Mensaje en un blog\}. Recuperado de: https://congresoeducacionartisticayvisual.wordpress.com/sobre-artivismo/

Ministerio de Educación. Aulas de verano : principios. (2011). Formas de expresión y creaciones propias: la competencia cultura y artística. Recuperado de: https://sede.educacion.gob.es/publiventa/ PdfServlet?pdf=VP15158.pdf\&area $=\mathrm{E}$

Moreno, M. I., Tirado de la Chica, A., López- Peláez, M. P., y Martínez, M. (2017). Investigación basada en las artes como Investigación Educativa: análisis de una experiencia en el colegio San Isidro en Guadalén. Educatio Siglo XXI, 35(1), 125-144.

Ortega , C.V. ( 2015). El artivismo como acción estratégica de nuevas narrativas artístico-políticas. Calle 14: revista de investigación en el campo del arte, 10 (15),pp.100-111 Recuperado de: http://www.redalyc.org/ articulo.oa?id=279038948008

Palacios, G.A. (2009). El arte comunitario: el origen y evolución de las prácticas artísticas colaborativas. Arteterapia: papeles de arteterapia y educación artística para la inclusión social,4,pp.197-211.

Palacios, L. (2006). El valor del arte en el proceso educativo. Reencuentro. Análisis de Problemas Universitarios, (46), pp-no numerado

Pinedo, M. ( sin fecha). El pensamiento divergente en el área plástica a través de retos (trabajo fin de grado). Campus Público María Zambrano, Segovia.

Romero, B. L. (2004). Arte terapia. Otra forma de curar. Educación y futuro: revista de investigación aplicada y experiencias educativas, 10, 101-110. 
Salazar X. y Olivos F. (eds.). Artivismo. Cambio social y activismo cultural. Lima: IESSDEH, UPCH.

Toso, D. (2009). Arte público colaborativo-participativo. La función pedagógica y transformadora del arte colaborativo. Arteterapia: papeles de arteterapia y educación artística para la inclusión social,4, pp.239243. 